\title{
Morkakens vekt betyr lite for svangerskapsforgiftning
}

\section{Svangerskapsforgiftning skyldes liten morkake, hevdes det ofte i lærebøker og fagartikler. En studie av 317688 svangerskap tyder på at dette ikke er korrekt.}

Er morkakevekten lavere i svangerskap med svangerskapsforgiftning enn i svangerskap uten svangerskapsforgiftning? Dette var utgangspunktet for vår studie som omfattet alle enlingesvangerskap i Norge i perioden 1999-2004 (1).

Svangerskapsforgiftning ble diagnostisert i $4 \%$ av alle svangerskap, og i $8,7 \%$ av disse var barnets fødselsvekt lavere enn 2,5-prosentilen (small for gestational age; SGA). Lav vekt var nært knyttet til liten morkake: I $60 \%$ av svangerskapene med barn med lav fødselsvekt var morkakens vekt i den laveste desil, dvs. blant de $10 \%$ minste både i svangerskap med og uten svangerskapsforgiftning.

I over $90 \%$ av alle svangerskap med svangerskapsforgiftning var ikke barnets vekt lavere enn 2,5-prosentilen. Om moren hadde svangerskapsforgiftning eller ikke, ga heller ikke stor forskjell i morkakevekt der barnet ikke hadde lav fødselsvekt. Svangerskap med svangerskapsforgiftning var likevel noe overrepresentert blant både de små og de store morkakene.

Studien tyder på at morkaken ikke er mindre i svangerskap med svangerskapsforgiftning. Det er barnets fødselsvekt som er sterkest knyttet til morkakens vekt. Vi har tidligere vist at risiko for å få et barn med svært lav fødselsvekt er litt høyere med enn uten svangerskapsforgiftning, gitt samme morkakevekt (2).

Mye tyder på at svangerskapsforgiftning ikke skyldes en liten morkake, og at morkakens grad av dysfunksjon ved svangerskapsforgiftning ikke kan måles ut ifra morkakevekt.

\section{Anne Eskild}

anne.eskild@medisin.uio.no

Kvinneklinikken

Akershus universitetssykehus

\section{Litteratur}

1. Eskild A, Vatten LJ. Do pregnancies with preeclampsia have smaller placentas? A population study of 317688 pregnancies with and without growth restriction in the offspring. BJOG 2010; doi: 10.1111/j.1471

2. Eskild A, Romundstad PR, Vatten LJ. Placental weight and birthweight: does the association differ between pregnancies with and without preeclampsia? Am J Obstet Gynecol 2009: 201: 595 e1-5.

\section{Sosioøkonomiske forhold og AD/HD hos barn}

Genetiske faktorer spiller en viktig rolle i utviklingen av AD/HD, men psykososiale forhold kan også ha betydning. Svenske forskere har undersøkt sammenhengen mellom forskrivning av AD/HD-medisiner og sosioøkonomiske indikatorer hos svenske skolebarn (Acta Pædiatrica 2010; 99: 920-4).

I Läkemedelsregistret ble det identifisert AD/HD-medisinering i 2006 for en nasjonal fødselskohort på 1,1 millioner barn i alderen 6-19 år. Lav utdanning hos mor, aleneforeldre og mottak av sosiale ytelser var forbundet med økt risiko for AD/HD-medisinering. Selv om den arvelige komponenten er sterk, antyder resultatene at det kan settes inn tiltak for å forebygge lidelsen.

\section{Barn med cøliaki \\ ofte født med keisersnitt}

Barn med cøliaki er oftere født med keiser snitt enn andre barn, men det var ingen økt forekomst av keisersnitt blant barn med inflammatorisk tarmsykdom, ifølge en retrospektiv pasient-kontroll-studie fra sykehus i Tyskland (Pediatrics 2010; 125 : e1433-40).

Studien omfattet 1950 barn. I kontrollgruppen var $17 \%$ født ved keisersnitt, mens andelen med cøliaki var signifikant høyere $(27,5 \%$, OR 1,8$)$. Forfatterne foreslår at endrede forutsetninger for tarmfloraen postnatalt kan forklare sammenhengen. Dette er den første studien som viser en assosiasjon mellom keisersnitt og senere cøliaki.

\section{Kan kalsiumtilskudd gi hjerteinfarkt?}

\section{Retningslinjer for behandling av osteoporose kan bli endret som følge av påvist sammenheng mellom kal- siumtilskudd og hjerteinfarkt.}

Flere studier har antydet at kalsiumrik kost beskytter mot vaskulær sykdom. Likevel har kalsiumtilskudd vært assosiert med økt risiko for kardiovaskulære hendelser. Nå har en internasjonal forskergruppe gjort en metaanalyse for å undersøke effekten av kalsiumtilskudd på kardiovaskulære hendelser (1).

I analysen inngikk randomiserte, placebokontrollerte studier av kalsiumtilskudd $>500 \mathrm{mg} / \mathrm{dag}$, deltakere med gjennomsnittsalder over 40 år og med studievarighet over et år. I studier med data på pasientnivå var hasardratio for å få hjerteinfarkt 1,31 , mens det ikke var signifikant økning $\mathrm{i}$ insidens av hjerneslag, død og det sammensatte endepunktet hjerteinfarkt, hjerneslag eller plutselig død. Metaanalysen av data på studienivå viste liknende resultater med sammenslått relativ risiko for hjerteinfarkt på 1,27.

- Disse resultatene er oppsiktsvekkende og kan få kliniske konsekvenser, sier professor Erik Fink Eriksen ved Avdeling for klinisk endokrinologi, Oslo universitetssykehus, Aker. Risikoøkning ble kun sett hos pasienter som fikk kalsiumtilskudd uten D-vitamin, og som gjennomsnittlig fikk mer enn 800 mg kalsium i kosten. I studier av

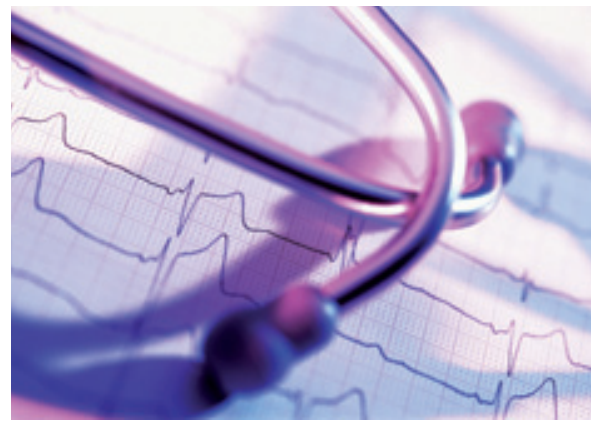

Illustrasjonsfoto Colourbox

kombinert tilskudd av kalsium og D-vitamin, som er standard ved osteoporosebehandling, er en liknende økning av kardiovaskulær risiko ikke observert.

- Resultatene vil nå bli drøftet i internasjonale ekspertkomiteer. Vi må avvente rapportene fra disse før behandlingsretningslinjer for osteoporose endres, sier Eriksen.

\section{Trine B. Haugen}

trine.b.haugen@hf.hio.no

Tidsskriftet

\section{Litteratur}

1. Bolland MJ, Avenell A, Baron JA et al. Effect of calcium supplements on risk of myocardial infarction and cardiovascular events: meta-analysis. BMJ 2010. 341: c3691. 